\title{
GAYA BAHASA MAMAH DEDEH PADA CERAMAH BERJUDUL "ISLAM DAN GAYA HIDUP”
}

\author{
Eko Agoes Setiawan \\ STID Al-Hadid, Surabaya \\ ekoagoes@stidalhadid.ac.id
}

\begin{abstract}
Abstrak: Penelitian ini mendeskripsikan gaya bahasa yang digunakan oleh Mamah Dedeh sebagai pendakwah pada ceramah yang berjudul "Islam dan Gaya Hidup" dengan menggunakan pendekatan teori gaya bahasa Gorys Keraf. Gaya Bahasa perlu diperhatikan oleh seorang dai ketika menyampaikan pesan dakwahnya, penggunaan gaya bahasa dipandang mampu memberikan efek penguatan makna sampai tataran alam bawah sadar seseorang. Gaya bahasa yang digunakan harus mampu untuk membuat pesan yang disampaikan melekat dalam benak jemaah. Studi ini menggunakan pendekatan kualitatif dengan teknik analisis gaya bahasa. Proses pengambilan data dilakukan dengan melakukan transkrip terhadap ceramah yang bersumber dari YouTube. Hasil yang didapatkan menunjukkan gaya bahasa yang digunakan saat pembukaan adalah personifikasi dan repetisi untuk membangun kesamaan pemahaman, pada isi menggunakan simile untuk mempermudah realitas, paradoks untuk memeprtegas maksud, erotesis-elipsisinuendo untuk penekanan dan memperdalam mengenai kehidupan dunia dan akherat. Tahap penutup menggunakan gaya bahasa personifikasi untuk pengingat pesan. Penggunaan gaya bahasa yang digunakan oleh Mamah Dedeh sangat berkaitan dengan tema pembahasan gaya hidup dalam Islam seperti cara berpakaian wanita dan cara berhias sampai dengan hidup bermewah-mewahan. Kata Kunci: Gaya Bahasa, Mamah Dedeh, Gaya Hidup Islam, Ceramah
\end{abstract}

MAMAH DEDEH'S FIGURATIVE LANGUAGE IN HER SERMON TITLED “ISLAM DAN GAYA HIDUP" Abstract: This research describes figurative language used by Mamah Dedeh, an Islamic preacher, in her sermon titled "Islam dan Gaya Hidup" under the approach of Gorys Keraf's figurative language theory. A preacher needs to pay attention on his/her figurative language when s/he conveys da'wah messages. Figurative language is considered as the one which can amplify a meaning to someone's subconscious. Types of figurative language used should be able to make messages which strongly attach to the mind of congregation. This study uses qualitative approach applying analysis technique of figurative language. Its data was collected from the sermon transcript in YouTube. It indicates that personification and repetition were applied during her introduction to build a common understanding, simile was used during the content to simplify realities, paradox was for amplifying the meaning, and erotesis-elipsis-inuendo was applied to emphasize and deepen on the world and hereafter's lives. At the end of her sermon, she used personification to remind her messages. The usage of figurative language used by Mamah Dedeh was so related to her theme of the lifestyle in Islam such as the way a woman dresses, the way a woman accessorizes, and lives in luxury.

Key words: Figurative Language, Mamah Dedeh, Islamic Lifestyle, Sermon 


\section{Pendahuluan}

Kegiatan dakwah merupakan kegiatan komunikasi antara seorang dai dan mad'uw. Dalam proses komunikasi tersebut seorang dai menyampaikan pesan yang bersumber dari Al-Qur'an dan Sunah dan berharap agar apa yang disampaikan mampu melekat dan diterima. ${ }^{1}$ Oleh karena itu, seorang dai perlu untuk memperhatikan dan mengatur setiap kata yang digunakan. Setiap dai perlu memiliki kesadaran dalam menggunakan kata-kata yang digunakan. Untuk dapat mengungkapkan perasaan atau pikiran tertentu serta menimbulkan keindahan dalam berkomunikasi diperlukan penggunaan gaya bahasa oleh seorang komunikator. Penggunaan gaya bahasa juga diperlukan dalam kegiatan dakwah untuk bisa membuat gagasan bisa diterima, melekat, dan terngiang oleh mad'uw. Penggunaan gaya bahasa yang tepat mampu membuat pesan yang disampaikan baik secara lisan maupun tulisan melekat dalam benak mad'uw. Salah satu studi menunjukkan penggunaan gaya bahasa dalam sebuah cerpen mampu memberikan beberapa dampak seperti membuat lebih hidup dan menarik apa yang disampaikan, di

\footnotetext{
1 Mubasyaroh, "Dakwah Dan Komunikasi (Studi Penggunaan Media Massa Dalam Dakwah)," Jurnal Komunikasi Penyiaran Islam 4, no. 1 (2016): 95-114, doi:10.21043/at-tabsyir.v4i1.2908.

2 Obi Samhudi, Chairil Effendy, and Christanto Syam, "Jenis Dan Fungsi Gaya Bahasa Dalam Pemaknaan Kumpulan Cerpen Kembalinya Tarian Sang Waktu: Stilistika," Jurnal Pendidikan Dan Pembelajaran

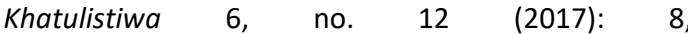
https://jurnal.untan.ac.id/index.php/jpdpb/article/vie w/23107.

3 Adrina Inayati Utami, Reni Nuraeni, and Syarif Maulana, "Representasi Wanita Sosialita Dalam Iklan ( Analisis Semiotika Roland Barthes Pada Iklan Televisi Magnum Versi Pink and Black ) Representation of Socialite Woman in Advertising ( Semiotic Analysis of Roland Barthes in Television Advertising of Magnum Pink," E-Proceeding of Management 2, no. 3 (2015): 4285 ,
}

sisi lain juga bisa meningkatkan selera pembaca atau pendengar dan juga memperkuat gagasan dalam bercerita. ${ }^{2}$

Pemilihan judul artikel tersebut juga didasarkan pada pertimbangan, yakni mengenai fenomena gaya hidup bermewahan yang muncul dalam masyarakat, beberapa temuan menjelaskan bahwa banyak sekali paparan mengenai gaya hidup mewah atau berlebihan dari berbagai media seperti iklan televisi, ${ }^{3}$ film ${ }^{4}$ dan juga novel. ${ }^{5}$ Studi lainnya, juga menjelaskan ada hubungan antara gaya hidup mewah dengan perilaku konsumtif, ${ }^{6}$ pada tataran tertentu gaya hidup mewah atau berlebihan ini juga bisa mengarahkan kepada perilaku kriminal seperti trafficking anak. ${ }^{7}$ Fenomena ini, tentu perlu direspons oleh pendakwah yang ada, dengan pemberian pesan dakwah, yang bisa diterima oleh masyarakat luas. Pesan dakwah yang disampaikan juga, perlu mempertimbangkan penggunaan gaya bahasa yang sesuai agar bisa diterima oleh pendengar. Dari sekian banyak pendakwah yang ada, salah satu sosok yang juga menyampaikan tentang gaya hidup Islam adalah Mamah Dedeh. Mamah Dedeh, ternyata memiliki pandangan mengenai

https://openlibrarypublications.telkomuniversity.ac.id /index.php/management/article/view/2442.

${ }^{4}$ Stefanny Harlie and Widayatmoko Widayatmoko, "Analisis Wacana Perilaku Konsumtif Dalam Film Crazy Rich Asian," Koneksi 2, no. 2 (2019): 587, doi:10.24912/kn.v2i2.3940.

5 Burhanuddin Aulia, "Hedonisme Dalam Novel Antologi Rasa Karya Ika Natassa," Jurnal Bahasa Dan Sastra 6, no. 3 (2019): 141-42 doi:10.24036/81037410

${ }^{6}$ Ardilla Saputri and Risana Rachmatan, "Religiusitas Dengan Gaya Hidup Hedonisme: Sebuah Gambaran Pada Mahasiswa Universitas Syiah Kuala," Jurnal Psikologi 12, no. 2 (2017): 65, doi:10.24014/jp.v12i2.3230.

7 Muslim Sabarisman, "Gaya Hidup Hedonisme Dan Fenomena Trafficking Anak: Studi Kasus Di Kota Surabaya," Sosiokonsepsia 16, no. 2 (2011): 194, doi:10.33007/ska.v16i2.802. 
gaya hidup, dan dengan sosok beliau sebagai seorang ulama panutan di masyarakat yang juga memiliki gaya bahasa yang khas dalam setiap ceramahnya.

Penggunaan gaya bahasa sendiri tidak hanya terbatas pada karya tulis saja, melainkan juga digunakan dalam konteks promosi suatu produk. Berdasarkan salah satu studi tentang penggunaan gaya bahasa dalam suatu promosi, ditemukan bahwa gaya bahasa yang digunakan mampu untuk memperkuat penguatan makna produk serta memberikan efek sampai dengan tataran alam bawah sadar seseorang. ${ }^{8}$ Hal ini, memberikan makna bahwa penggunaan gaya bahasa sendiri mampu menimbulkan efek dalam suatu komunikasi, sehingga penggunaan gaya bahasa pastilah memiliki dampak yang diharapkan.

Penggunaan gaya bahasa untuk memberikan efek komunikasi pada berbagai media komunikasi juga diiringi dengan berkembangnya konsep kegiatan dakwah yang saat ini sudah merambah ke televisi sebagai upaya untuk menyampaikan gagasan keagamaan pada diri mad'uw atau jemaah. Kegiatan dakwah saat ini tidak hanya berfokus pada kegiatan di masjid atau mimbar ceramah, melainkan sudah masuk ke televisi. Perkembangan ini, tentu juga diiringi dengan semakin luasnya daya jangkau jemaah yang bisa menyaksikan kegiatan dakwah tersebut. Berbagai stasiun

8 Deary Pratama Husen and Agus Wartiningsih, "Analisis Gaya Bahasa Dalam Slogan Makanan Ringan," Jurnal Penddikan Dan Pembelajaran Khatulistiwa 7(9) (2018):

8 , https://jurnal.untan.ac.id/index.php/jpdpb/article/vie w/28868

${ }^{9}$ Komisi Penyiaran Indonesia, Survei Indeks Kualitas Program TV Periode II (April-Juni) 2018, 2018, http://www.kpi.go.id/index.php/id/umum/38-dalamnegeri/34754-hasil-survey-indeks-kualitas-programtv-periode-ii-april-juni-2018. televisi mengadakan kegiatan dakwah yang hal ini ternyata mendapatkan respons yang positif dari masyarakat. Menurut Komisi Penyiaran Indonesia (KPI), program tayangan religi memiliki indeks 3,15 dari skala 1-5. Hal ini, jika dibandingkan dengan jenis acara lainnya, menempatkan program religi sebagai program dengan nilai yang cukup baik dibawah wisata/budaya $(3,33)$, talk show $(3,22)$. Capaian nilai ini, membuat program tayangan religi termasuk program yang masuk kriteria berkualitas berdasarkan indeks KPI yakni 3,00. ${ }^{9}$ Di antara banyaknya program religi di televisi, salah satu pendakwah dalam program religi yang cukup menjadi sorotan adalah Mamah Dedeh. Menurut hasil survey Komisi Penyiaran Indonesia (KPI), menyebutkan bahwa program Mamah dan Aa Beraksi di Indosiar menempati posisi pertama dengan persentase $44,7 \%$. Survei ini menyebutkan bahwa program Mamah dan Aa Beraksi di Indosiar adalah program yang paling banyak ditonton pada tahun 2015. ${ }^{10}$ Program Mamah dan Aa Beraksi ini, juga pernah memiliki pengaruh terhadap masyarakat khususnya remaja, ditemukan adanya korelasi program Mamah Dedeh terhadap kesadaran remaja akan bahaya zina. ${ }^{11}$

Pengaruh ini bisa dipahami, karena pengisi acara tersebut adalah Mamah Dedeh yang juga menjadi ulama panutan berdasarkan hasil survei tahun 2017 saat menyampaikan

\footnotetext{
10 Tempo, "Mamah Dedeh: Program Religi Televisi Terpopuler," Tempo, accessed November 15, 2019, https://seleb.tempo.co/read/728412/Mamah-Dedehprogram-religi-televisi-terpopuler-2015.

11 Atha Zhafira, "Pengaruh Program Mamah Dan Aa Beraksi Episode 'Nistanya Zina Dan Penyimpangan Seksual' Terhadap Tingkat Kesadaran Remaja Akan Bahaya Zina (Survey Pada Siswa/Siswi Sman 87 Dki Jakarta" (Skripsi UIN Syarif Hidayatullah, 2017), iv, https://repository.uinjkt.ac.id/dspace/handle/123456
} $789 / 35337$. 
ceramah dengan hasil survei menyebutkan $25,3 \%{ }^{12} \mathrm{Hal}$ ini dipandang wajar, karena Mamah Dedeh merupakan dai yang memiliki kekhasan dalam penyampaian materi dakwahnya. Mamah Dedeh dikenal sebagai orang dengan gaya dakwahnya yang ceplasceplos dan apa adanya, penyampaian yang tegas dengan mimik wajah yang serius, namun mampu mengundang tawa jemaahnya. ${ }^{13}$ Gaya dakwah tersebut menarik kalangan netizen untuk membuat sebuah parodi dengan cara dakwah yang dilakukan oleh Mamah Dedeh. ${ }^{14} \mathrm{Hal}$ ini menunjukkan bahwa, gaya bahasa yang digunakan oleh Mamah Dedeh bisa diterima dan membekas dalam benak masyarakat. Pada satu kesempatan, tepatnya pada tahun 2016, Mamah Dedeh dalam program acaranya membahas tema tentang 'Islam dan Gaya Hidup'. Pada program tersebut, ketika berceramah Mamah Dedeh memberikan penjelasan tentang perempuan yang disamakan dengan makanan leupet atau lontong. Penggunaan gaya bahasa disini memiliki satu keunikan yakni, penggunaan realitas perempuan dengan makanan untuk menjelaskan gambaran gaya hidup yang tidak sesuai dengan hukum Islam. Hal ini, juga sesuai dengan beberapa temuan

12 Fajarina Nurin, "Terkenal Ceplas-Ceplos Mamah Dedeh Terpilih Jadi Ulama Penutan," Liputan6, accessed November 15, 2019, https://www.liputan6.com/showbiz/read/3138905/te rkenal-ceplas-ceplos-Mamah-Dedeh-terpilih-jadiulama-panutan.

13 Ahmad Zaini, "Retorika Dakwah Mamah Dedeh Dalam Acara 'Mamah \& Aa Beraksi' Di Indosiar," IImu Dakwah: Academic Journal for Homiletic Studies 11, no. 2 (2018): 219-34, doi:10.15575/idajhs.v11i2.1900. 14 Shafira Rianiesti Noor, "Gaya Dakwahnya Sering Dijadikan Parodi, Mamah Dedeh Justru Bangga Dan Bersyukur," Sripoku.com, accessed April 27, 2020, https://palembang.tribunnews.com/2018/06/11/gaya -dakwahnya-sering-dijadikan-parodi-Mamah-Dedehjustru-bangga-dan-bersyukur.

15 Nurmy A.R, "Gaya Bahasa Dakwah Di Daerah Pesisir," Al-Hikmah 10, no. 1 (2016): 40, doi:10.24260/al-hikmah.v10i1.545. mengenai perlunya menyesuaikan gaya bahasa dalam dakwah berdasarkan kondisi pendengar, perbedaan ini bisa terkait dengan kondisi geografis, karakter, dan stereotip yang dimiliki, setiap perbedaan pendengar tersebut perlu harus disikapi dengan cermat. ${ }^{15}$

Studi tentang gaya bahasa sendiri ada beberapa yakni, studi tentang gaya bahasa K.H. Zainuddin M.Z. pada kegiatan Isra Mikraj di Tangerang. ${ }^{16}$ Studi ini, menjelaskan gaya bahasa dengan menghubungkan terhadap fungsi masing-masing bagian ceramah yang dilakukan oleh K.H. Zainuddin M.Z. pada kegiatan Isra Mikraj di Tangerang. Selain itu juga, ada studi tentang gaya bahasa repetisi yang digunakan oleh Ustaz Yusuf Mansur dalam program Wisata Hati di ANTV. ${ }^{17}$ Studi ini, menjelaskan gaya bahasa repetisi yang digunakan oleh Ustaz Yusuf Mansur dalam acara tersebut. Hasilnya menjelaskan jenis-jenis repetisi yang dilakukan oleh Ustaz Yusuf Mansur. Studi lain menjelaskan, kemampuan Mamah Dedeh dalam penggunaan gaya bahasa, penggunaan diksi, variasi bahasa, dan intonasi dalam ceramah dalam program ANTV. ${ }^{18}$ Studi ini, menjelaskan gaya bahasa

16 Eka Anjani, "Gaya Bahasa K.H. Zainuddin M.Z. Dalam Ceramah Isra Mikraj Di Tanggerang Selatan," Inteleksia-Jurnal Pengembangan IImu Dakwah Vol 1, no. 010191 http://inteleksia.stidalhadid.ac.id/index.php/inteleksi a/article/view/17.

17 Ninit Alfianika, "BAHASA BETAWI DAN GAYA BAHASA REPETISI DALAM CERAMAH USTAD YUSUF MANSUR PROGRAM WISATA HATI DI ANTV," JURNAL GRAMATIKA 1 , no. 1 (2016): 121 , doi:10.22202/jg.2015.v1i1.1161.

${ }^{18}$ Alfi Syahrin, "Kajian Retorika Dakwah Mamah Dedeh Akselerasi Pemahaman Dalam Seni Berbicara," Pendidikan Almuslimin Volume 3, no. 2 (2015): 1 http://jfkip.umuslim.ac.id/index.php/jupa/article/vie w/413. 
Mamah Dedeh berdasarkan struktur kalimat dan ditemukan penggunaan gaya bahasa klimaks, antiklimaks, dan repetisi dalam ceramah Mamah Dedeh. Berdasarkan studi tentang gaya bahasa Mamah Dedeh, sejauh yang telah disampaikan, penjelasan gaya bahasa banyak ditinjau berdasarkan struktur kalimat, dan tidak menjelaskan gaya bahasa berdasarkan tidak langsungnya makna, dalam studi ini nantinya akan mencoba menjelaskan mengenai gaya bahasa dengan melihat langsung tidaknya makna yang digunakan oleh Mamah Dedeh dalam ceramah yang berjudul 'Islam dan Gaya Hidup'. Mamah Dedeh dengan gaya bahasa yang khas dan statusnya sebagai salah satu ulama panutan dalam masyarakat, dipandang perlu untuk diteliti lebih mendalam mengenai gaya bahasa yang digunakan dalam ceramah yang berjudul 'Islam dan Gaya Hidup'.

Ceramah yang disampaikan sudah berjalan dan bisa dikatakan sudah lama, namun pesan dakwah yang disampaikan dipandang masih memiliki relevansi dengan situasi masyarakat saat ini. Selain relevansi dengan situasi masyarakat, dalam ceramah tersebut juga dipandang memiliki keunikan dalam penggunaan gaya bahasanya, hal ini bisa dilihat dari beberapa contoh penggunaan gaya bahasa yang khas seperti menyamakan pakaian perempuan yang tidak sesuai syariat dengan makanan leupet. Penggunaan gaya bahasa ini dipandang memiliki kesan yang berbeda ketika disampaikan kepada jemaah. Berdasarkan latar belakang tersebut, studi ini bertujuan untuk menguraikan penggunaan gaya bahasa yang digunakan

19 Indosiar, "Islam Dan Gaya Hidup" video youtube, 12.01, posted by "Indosiar", desember 14, 2016. https://www.youtube.com/watch?v=98x04eljKd0 oleh Mamah Dedeh pada ceramah yang berjudul 'Islam dan Gaya Hidup'. Studi ini, menggunakan pendekatan kualitatif deskriptif dengan menekankan pada penggunaan gaya bahasa yang dipakai. Untuk proses analisisnya lebih menekankan pada sesi ceramah yang dilakukan oleh Mamah Dedeh tanpa sesi tanya jawab dengan penonton atau jemaah. Hal ini dikarenakan sesi ceramah menunjukkan secara keseluruhan isi pesan yang hendak disampaikan oleh Mamah Dedeh dalam program tersebut. Secara kesediaan sumber data juga tidak terdapat sesi tanya jawab pada episode ceramah tersebut. Sehingga, gaya bahasa yang dijelaskan adalah ketika beliau menyampaikan sesi ceramah utama. Dalam pengumpulan data menggunakan teknik dokumentasi video, dari video ceramah Mamah Dedeh berjudul 'Islam dan Gaya Hidup' ${ }^{19}$ tersebut akan ditranskripkan dalam bentuk teks yang akan menjadi bahan untuk analisis. Metode validasi data menggunakan peningkatan ketekunan. Ketekunan yang dimaksud adalah melakukan pengamatan secara lebih cermat dan berkesinambungan untuk memastikan bahwa, data atau peristiwa yang didapatkan bersifat pasti dan sistematis. ${ }^{20}$ Cara yang dilakukan adalah melakukan pembacaan secara berulang pada transkip ceramah. Metode analisis data berdasarkan Miles dan Huberman terdiri dari tiga tahap yakni data reduction, data display, dan conclusion drawing/verification. ${ }^{21}$

\section{Ceramah}

Ceramah merupakan salah satu metode komunikasi yang dilakukan dengan sasaran

\footnotetext{
${ }^{20}$ Sugiyono, Metode Penelitian Pendidikan Pendekatan Kuantitatif, Kualitatif, Dan R\&D (Bandung: Alfabeta, 2015), 370.

${ }^{21}$ Sugiyono, Metode Penelitian Kuantitatif Kualitatif Dan R\&D (Bandung: Alfabeta, 2012), 246.
} 
publik atau orang banyak. Metode ini juga dikenal dengan istilah public speaking. Menurut Abdul Abuddin Nata, menjelaskan metode ceramah penyampaian yang dilakukan oleh pembicara (pendakwah) dengan penuturan atau penjelasan lisan secara langsung di hadapan peserta (jemaah). Ceramah dimulai dengan menjelaskan tujuan yang ingin dicapai, menyingkap garis besar pembicaraan, serta menghubungkan antar materi yang disajikan. Ceramah akan berhasil apabila mendapatkan perhatian yang sungguhsungguh dari peserta didik (jemaah), disajikan secara sistematik, menggairahkan, memberi kesempatan kepada peserta. ${ }^{22}$

Menurut Nizar dan Hasibuan, ceramah adalah metode yang memberikan penjelasan sebuah materi. Biasa dilakukan di depan beberapa orang. Metode ini menggunakan bahasa lisan. Peserta biasanya duduk sambil mendengarkan penjelasan materi yang disampaikan. ${ }^{23}$ Susunan ceramah terdiri dari tiga hal yakni pembukaan, isi dan penutup. Menurut Ali Aziz, pembukaan memiliki orientasi untuk mengantarkan pikiran dan menambahkan perhatian kepada pokok pembicaraan. ${ }^{24}$ Sedangkan, untuk isi adalah inti pesan yang hendak disampaikan dalam ceramah, ada beberapa cara yang bisa digunakan yakni dengan cara induktif dan deduktif. Induktif menggunakan alur berpikir yang khusus sedangkan deduktif menggunakan alur berfikir yang umum. ${ }^{25}$ Ada bagian akhir atau penutup memiliki fungsi memfokuskan

\footnotetext{
22 Abuddin Nata, Perspektif Islam Tentang Strategi Pembelajaran (Jakarta: Kencana Prenada Media Grup, 2011), 181-82.

23 Samsul dan Zainal Efendi Hasibuan Nizar, Hadis Tarbawi, Membangun Kerangka Pendidikan Ideal Perspektif Rasulullah (Jakarta: Kalam Mulia, 2011), 58.
}

pikiran dan gagasan pendengar kepada gagasan utama yang disampaikan. Ada beberapa cara yang bisa digunakan yakni menyampaikan ikhtisar; mengatakan gagasan dengan kalimat yang singkat; memberikan dorongan untuk bertindak; diakhiri dengan klimaks; menyatakan kutipan sajak, kitab suci, peribahasa atau ucapan ahli; menceritakan contoh-contoh dan menjelaskan maksud sebenarnya pribadi pembicara. ${ }^{26}$ Susunan ini, nantinya akan digunakan sebagai alat analisis di dalam ceramah Mamah Dedeh dan menghubungkan dengan tujuan dari setiap tahapan ceramah yang ada.

\section{Gaya Bahasa}

Menurut Gorys Keraf, gaya bahasa atau style adalah cara mengungkapkan pikiran melalui bahasa secara khas yang memperlihatkan jiwa dan kepribadian pemakai bahasa. ${ }^{27}$ Gaya bahasa dibagi atas dua hal yakni, dari segi nonbahasa dan dari segi bahasa. Dalam segi bahasa dibagi atas empat hal yakni berdasarkan pilihan kata, berdasarkan nada, berdasarkan struktur kalimat, dan berdasarkan langsung tidaknya makna. ${ }^{28} \mathrm{Jika}$ dilihat dari langsung tidaknya makna ada dua jenis yakni gaya bahasa retorika dan gaya bahasa kiasan.

Gaya bahasa berdasarkan pilihan kata terdiri dari atas: (a) gaya bahasa resmi adalah gaya yang bentuknya lengkap, dipergunakan dalam kesempatan-kesempatan resmi seperti, amanat kepresidenan, berita negara, khotbah mimbar, tajuk rencana,

\footnotetext{
${ }^{24}$ Ali Aziz, Ilmu Dakwah Edisi Revisi (Surabaya: Prenada Media Group, 2016), 359.

${ }^{25}$ Ibid., 363.

26 Ibid., 365

27 Gorys Keraf, Diksi Dan Gaya Bahasa (Jakarta: Gramedia Pustaka Utama, 2010), 112.

28 Ibid., 116-117.
} 
pidato-pidato penting. Contohnya, "Bahwa sesungguhnya kemerdekaan ini dialah hak segala bangsa dan oleh sebab itu, maka penjajahan di atas dunia harus dihapuskan, karena tidak sesuai dengan perikemanusiaan dan peri-keadilan"; ${ }^{\prime 2}$ (b) gaya bahasa tidak resmi adalah gaya bahasa yang dipergunakan dalam bahasa standar, khususnya dalam kesempatan-kesempatan tidak formal. Gaya ini dipergunakan dalam karya tulis, buku pegangan, akrtikel mingguan, editorial, kolumnis. Contohnya, Sumpah Pemuda yang dicetuskan pada tanggal 28 Oktober 1928 adalah peristiwa nasional, yang mengandung benis nasionalisme. Sumpah Pemuda dicetuskan pada zaman penjajahan. Nasionalisme pada zaman penjajahan mempunyai watak khusus yakni anti penjajahan; ${ }^{30}$ (c) gaya bahasa percakapan adalah gaya bahasa yang menggunakan kata-kata populer dan katakata percakapan. Contohnya, pertanyaan yang pertama, di sini memang segaja saya tidak membedakan antara istilah jenis kata atau word classes atau parts of speech. Jadi ketiganya saya artikan sama di sini. ${ }^{31}$

Gaya bahasa berdasarkan nada terdiri dari: (a) gaya sederhana adalah gaya yang cocok untuk memberi instruksi, perintah, pelajaran, perkuliahan, dan sejenisnya. Gaya ini cocok untuk menyampaikan fakta-fakta atau pembuktian-pembuktian; ${ }^{32}$ (b) gaya mulia dan bertenaga adalah gaya yang penuh dengan vitalitas dan energi, dan biasanya dipergunakan untuk menggerakkan sesuatu; ${ }^{33}$ (c) gaya menengah adalah gaya yang diarahkan ekapda usaha untuk

\footnotetext{
${ }^{29}$ Keraf, Diksi Dan Gaya Bahasa, 117.

${ }^{30}$ Ibid., 118-19.

${ }^{31}$ Ibid., 120.

32 Ibid., 121.

${ }^{33}$ Ibid., 122.
}

menimbulkan suasana senang dan damai, untuk mencapai suasana tersebut nadanya juga ersifat lemah-lembut, penuh kasih sayang, dan mengandung humor yang sehat. $^{34}$

Gaya bahasa berdasarkan struktur kalimat terdiri atas: (a) gaya bahasa klimaks adalah gaya bahasa yang mengandung urutanurutan pikiran yang setiap kali semakin meningkat kepentingannya dari gagasangagasan sebelumnya. Contohnya, dalam dunia perguruan tinggi yang dicengkam rasa takut dan rasa rendah diri, tidak dapat diharapkan pembaharuan, kebanggan akan hasil-hasil pemikiran yang obyektif atau keberanian untuk mengungkapkan pendapat secara bebas;; (b) gaya bahasa antiklimaks adalah gaya bahasa yang merupakan suatu acuan yang gagasannya diurutkan dari yang terpenting berturutturut ke gagasan yang kurang penting. Contohnya, pembangunan limat tahun telah dilancarkan serentak di Ibu kota negara, ibu kota - ibu kota propinsi, kabupaten, kecamatan, dan semua desa di seluruh Indonesia; ${ }^{36}$ (c) gaya bahasa paralelisme adalah gaya bahasa yang berusaha mencapai kesejajaran dalam pemakaian kata-kata atau frasa-frasa yang menduduki fungsi yang sama dalam bentuk gramatikal yang sama. Contohnya, baik golongan yang tinggi maupun golongan yang rendah, harus diadili kalau bersalah; ${ }^{37}$ (d) gaya bahasa antitesis adalah gaya bahasa yang mengandung gagasan yang bertentangan, dengan mempergunakan kata-kata atau kelompok kata yang berlawanan. Contohnya, mereka

\footnotetext{
${ }^{34}$ Ibid.

${ }^{35}$ Ibid., 124

${ }^{36}$ Ibid., 125.

${ }^{37}$ Ibid., 126
} 
sudah kehilangan banyak dari harta bendanya, tetepi mereka juga telah banyak memperoleh keuntungan daripadanya, serta kaya-miskin, tua-muda, besar-kecil, semuanya mempunyai kewajiban terhadap keamanan bangsa dan Negara; ${ }^{38}$ (e) gaya bahasa repetisi adalah gaya bahasa dengan perulangan bunyi, suku kata, kata atau bagian kalimat yang dianggap penting untuk memberi tekanan dalam sebuah konteks yang sesuai. Contohnya, maukah kau pergi bersama serangga-serangga tanah, pergi bersama kecoak-kecoak, pergi bersama mereka yang menyusupi tanah, menyusupi alam? ${ }^{39}$

Gaya bahasa kiasan terbagi atas: (a) persamaan atau simile adalah membandingkan sesuatu dengan hal yang lain secara eksplisit. Persamaan ini diwujudkan dalam kata-kata seperti, sama, sebagai, bagaikan, laksana dan sebagainya. Contohnya, bibirnya seperti delima merekah; ${ }^{40}$ (b) Metafora adalah membandingkan dua hal secara langsung namun dalam bentuk yang singkat. Contohnya, bunga bangsa, buaya darat; ${ }^{41}$ (c) Personifikasi atau prosopopeia adalah gaya bahasa yang menggambarkan benda-benda mati atau barang-barang tidak bernyawa seperti memiliki sifat kemanusiaan. Contohnya, angin yang meraung di tengah malam yang gelap itu menambah lagi ketakutan kami; ${ }^{42}$ (d) Alusi adalah memberikan kesamaan antara orang, tempat atau peristiwa. Contohnya, Bandung adalah Paris Jawa; ${ }^{43}$ (e) Eponim adalah gaya

\footnotetext{
38 Ibid.

${ }^{39}$ Ibid., 127.

40 Ibid., 138.

41 Ibid., 139.

42 Ibid., 140.

43 Ibid., 141.
}

bahasa yang menghubungkan antara nama seseorang dengan sifat tertentu. Contohnya, hercules untuk menunjukkan kekuatan; ${ }^{44}$ (f) Epitet adalah menyatakan sifat atau ciri khusus dari seseorang atau suatu hal yang dengan hal itu menjelaskan atau menggantikan nama seseorang atau suatu barang. Contohnya, raja rimba untuk singa; ${ }^{45}$ (g) Sinekdoke adalah gaya bahasa yang mempergunakan sebagain dari sesuatu untuk menyatakan keseluruhan atau sebaliknya. Contohnya, setiap kepala dikenakan sumbangan sebesar seribu rupiah. $^{46}$

Selain itu, terdapat jenis lainnya yakni; (h) Metonimia adalah gaya bahasa untuk menyatakan suatu hal lain karena memiliki pertalian. Hubungan ini bisa berupa penemu untuk hasil temuannya, pemilik untuk barang yang dimiliki, akibat untuk sebab, sebab untuk akibat, isi untuk menyatakan kulitnya; ${ }^{47}$ (i) Hipalase adalah gaya bahasa menggunakan sebuah kata tertentu untuk menerangkan sebuah kata yang seharunya digunakan pada kata yang lain. Contohnya, ia berbaring di atas sebuah bantal yang gelisah; ${ }^{48}$ (j) Ironi adalah gaya bahasa yang memiliki maksud untuk mengingkari maksud sebenarnya. Contohnya, tidak diragukan lagi bahwa andalah orangnya, sehingga semua kebijaksanaan terdahulu harus dibatalkan seluruhnya! ${ }^{49}$ (k) Satire adalah gaya bahasa yang digunakan untuk menertawakan atau menolak sesuatu; ${ }^{50}$ (I) Inuendo adalah gaya bahasa sindiran dengan mengecilkan kenyataan yang sebenarnya. Contohnya,

\footnotetext{
44 Ibid.

45 Ibid.

46 Ibid., 142.

47 Ibid.

48 Ibid.

49 Ibid., 143.

50 Ibid.
} 
setiap kali ada pesta, pasti ia akan sedikit mabuk karena terlalu kebanyakan minum; 51 (m) Antifrasis adalah gaya bahasa yang bersifat ironi namun bermakna kebalikannya. Hal ini, hanya bisa diketahui jika sama-sama melihat realitas kemudian apa yang disampaikan berkebalikan. Contohya, adalah lihatlah sang raksasa telah tiba (realitasnya adalah orang cebol)..$^{52}$ (n) Paronomasi adalah gaya bahasa dengan mempergunakan kemiripan bunyi, namun memiliki perbedaan besar dalam maknanya. Contohnya, adalah tanggal dua gigi saja tanggal dua. ${ }^{53}$

Untuk gaya bahasa retoris terbagi atas: (a) aliterasi adalah gaya bahasa yang berwujud pengulangan konsonan yang sama. Contohnya, adalah takut titik lalu tumpah; ${ }^{54}$ (b) Asonansi adalah gaya bahasa yang berwujud perulangan bunyi vokal yang sama untuk memperoleh efek penekanan. Contohnya, adalah ini muka penuh luka siapa punya; $; 5$ (c) Anastrof adalah gaya bahasa dengan pembalikan susunan kata yang biasa dalam kalimat. Contohnya, pergilah ia meninggalkan kami, keheranan kami melihat perangainya; ${ }^{56}$ (d) Apofasis adalah gaya bahasa untuk menegaskan sesuatu tetapi tampaknya menyangkal atau berpura-pura membiarkan sesuatu namun menekankan hal itu. Contohnya, saya tidak mau mengungkapkan dalam forum ini bahwa saudara telah menggelapkan ratusan juta rupiah uang Negara; ${ }^{57}$ (e) Apostrof adalah gaya bahasa pengalihan amanat dari para hadirin kepada sesuatu yang tidak hadir. Contohnya, hai kamu dewa-dewa

51 Ibid.

52 Ibid., 144-145.

53 lbid., 145.

54 Ibid., 130.

55 Ibid.

56 Ibid. yang berada di surga, datanglah dan bebaskanlah kami dari belenggu penindasan ini. $^{58}$

Selain itu, jenis lainnya adalah; (f) Asindeton adalah gaya bahasa berupa acuan padat yang terdiri dari beberapa kata, frasa atau klausa sederajat. Contohnya, Dan kesesakan, kepedihan, kesakitan, seribu derita detik-detik penghabisan orang melepaskan nyawa; 59 (g) Polisidenton adalah gaya bahasa yang padat dan setara yang dihubungkan dengan kata sambung. Contohnya, dan ke manakah burung-burung yang gelisah dan tak berumah dan tak menyerah pada gelap dan dingin yang bakal merontokkan bulu-bulunya?; ${ }^{60}$ (h) Kiasmus adalah gaya bahasa yang terdiri dari dua bagian yang setara dan dipertentangkan satu sama lain dengan susunan frasa yang terbalik. Contohnya, semua kesabaran kamu sudah hilang, lenyap sudah ketekunan kamu untuk melanjutkan usaha itu; ${ }^{61}$ (i) Elipsis adalah gaya bahasa yang menghilangkan suatu unsur kalimat yang dengan mudah dapat diisi atau ditafsirkan sendiri oleh pembaca atau pendengar. Contohnya, "masihkah kau tidak percaya bahwa dari segi fisik engkau tak apa-apa, badanmu sehat; tetapi psikis..."62

Selanjutnya, ada jenis; (j) Eufemisme adalah gaya bahasa berupa ungkapan yang tidak menyinggung perasaan orang atau ungkapan halus untuk menggantikan acuan yang mungkin menghina atau menyinggung perasaan atau sesuatu yang tidak menyenangkan. Contohnya, ayahnya sudah tidak ada di tengah-tengah mereka

\footnotetext{
57 Ibid.

58 Ibid., 131.

59 Ibid.

60 lbid.

61 Ibid., 132.

62 Ibid.
} 
(=mati) ${ }^{63}$ (k) Litotes gaya bahasa yang dipakai untuk menyatakan sesuatu dengan tujuan merendahkan diri atau kurang dari keadaan sebenarnya. Contohnya, saya tidak akan merasa bahagia bila mendapat warisan satu milyar rupiah; ${ }^{64}$ (I) Histeron Proteron adalah gaya bahasa yang kebalikan dari sesuatu yang logis atau wajar, seperti menempatkan sesuatu yang terjadi kemudian pada awal peristiwa. Contohnya, jendela ini telah memberi sebuah kamar padamu untuk dapat berteduh dengan tenang; ${ }^{65}(\mathrm{~m})$ Pleonasme adalah gaya bahasa dengan mempergunakan kata-kata lebih banyak daripada yang diperlukan untuk menyatakan suatu gagasan. Contohnya, saya telah mendengar hal itu dengan telinga saya sendiri,66 (n) Perifrasis adalah gaya bahasa yang mempergunakan lebih banyak kata dari yang diperlukan dan bisa diganti dengan satu kata saja. Contohnya, jawaban bagi permintaan saudara adalah tidak = ditolak). ${ }^{67}$

Selanjutnya, ada jenis; (o) Prolepsis adalah gaya bahasa yang mempergunakan terlebih dahulu kata sebelum peristiwa atau gagasan yang sebenarnya terjadi. Contohnya, pada pagi yang naas itu, ia mengendarai sebuah sedan biru, ${ }^{68}(p)$ Erotesis adalah gaya bahasa yang sama sekali tidak menghendaki jawaban. Contohnya, Rakyatkah yang harus menanggung akibat semua korupsi dan manipulasi di negara ini? ${ }^{69}$; (q) Silepsis adalah gaya bahasa dengan mempergunakan dua konstruksi rapatan dengan menghubungkan sebuah kata dengan dua kata lain yang sebenarnya hanya

\footnotetext{
63 Ibid.

64 Ibid.

65 Ibid., 133.

66 Ibid., 133.

67 Ibid., 134.

68 Ibid., 134.
}

salah satunya mempunyai hubungan dengan kata pertama. Contohnya, ia sudah kehilangan topi dan semangatnya; ${ }^{70}$ ( $r$ ) Koreksio adalah gaya bahasa yang awalnya menegaskan sesuatu namun kemudian memperbaikinya. Contohnya, sudah empat kali saya mengunjungi daerah itu, ah bukan, sudah lima kali; ${ }^{71}$ (s) Hiperbol adalah gaya bahasa yang mengandung penyataan berlebihan dan membesar-besarkan sesuatu. Contohnya, kemarahanku sudah menjadi-jadi hingga hampir-hampir meledak $a k u ; 72(\mathrm{t})$ Paradoks adalah gaya bahasa yang mengandung pertentangan yang nyata dengan fakta-fakta yang ada. Contohnya, musuh sering merupakan kawan yang $a k r a b ;^{73}$ (u) Oksimoron adalah gaya bahasa yang menggabungkan kata-kata untuk mencapai efek yang bertentangan. Contohnya, keramah-tamahan yang bengis. $^{74}$

\section{Profil Mamah Dedeh}

Mamah Dedeh merupakan salah satu penceramah yang tampil di televisi swasta. Nama lengkapnya adalah Dedeh Rosidah. Beliau merupakan penceramah kelahiran Jawa Barat pada tanggal 5 Agustus 1951. Mamah Dedeh memiliki karakter logat khas Sunda dengan suara yang lantang. Logat bicaranya sudah terbentuk sejak kecil karena kebiasaannya sehari-hari. Setelah lulus dari sekolah dasar, beliau melanjutkan ke pendidikan agama di Jakarta. Beliau menikah dengan putra seorang kiai. Dari sinilah karir beliau dalam dunia dakwah kian meningkat. Kurang lebih sudah lebih dari 10 tahun beliau

\footnotetext{
69 Ibid., 134.

70 Ibid., 135.

71 Ibid., 135.

72 Ibid., 135.

73 Ibid., 136.

74 Ibid., 136.
} 
menjadi pendakwah atau penceramah melalui Indosiar. Tepatnya mulai tahun 2007. ${ }^{75}$ Kebiasaan berdakwah tetap dilakukan saat menjadi mahasiswa. Saat sabtu-minggu libur, beliau keluar asrama dengan teman-temannya kemudian berceramah di sekitar Ciputat. Beliau juga sempat berdakwah melalui radio. Pada tahun 1994, aktor Benyamin Sueb pemilik radio Betawi Bens Radio meminta Mamah Dedeh mengisi program Ngaji setiap hari jumat. Namanya bisa masuk karena ada salah satu karyawan radio tersebut yang memberikan rekomendasi. Karakternya yang ceplas-ceplos sesuai atau mirip dengan karakter Bens Radio mendapatkan respon yang bagus dari para pendengar. Dari situlah kemudian beliau dikenal dan dikontrak melalui televisi. ${ }^{76}$

\section{Ceramah Mamah Dedeh Berjudul "Islam \& Gaya Hidup"} Program ceramah Mamah Dedeh menjelaskan terlebih dahulu selama kurang lebih 10 menit mengenai pembahasan tema pada ceramah "Islam dan Gaya Hidup", dalam ceramah ini Mamah Dedeh tidak menerima atau belum membuka pertanyaan dari para penonton, dalam sesi pertama ini Mamah Dedeh berceramah dengan cara satu arah, yakni Mamah Dedeh menyampaikan isi ceramahnya, sedangkan para penonton mendengarkan dan belum diperkenankan mengajukan pertanyaan.

Pembukaan ceramah Mamah Dedeh menyampaikan: Islam dan gaya hidup. Islam itu agama yang syarat dengan aturan. Makanya masuk Islam harus kaffah. Al

\footnotetext{
75 Zaini, "Retorika Dakwah Mamah Dedeh Dalam Acara 'Mamah \& Aa Beraksi' Di Indosiar," 226.

76 Viva.co.id, "Profil Mamah Dedeh," Viva, accessed April

27,

2020
}

Baqarah 208: "hai orang-orang yang beriman masuklah Islam. Kaffah. Keseluruhan dari mulai gaya hidup, cara berpakaian, cara bicara, bagaimana kita bermuamalah, bagaimana kita beribadah, itu yang Allah katakan Kaffah. Semuanya, jangan pilih kasih. Jangan mengikuti langkah setan, setan musuh yang nyata, artinya kalau orang ngaku Islam tapi sikap perilaku kalimat kata-katanya tidak Islami Islamnya tidak Kaffah.

Isi ceramah Mamah Dedeh menyampaikan: Saya ambil contoh dari mulai kata-kata pergaulan pakaian semuanya itu adalah dinilai oleh Allah dipertanggungjawabkan namun yang Jangan lupa kita tahu sekarang era globalisasi era perkembangan teknologi dan industri sehingga yang namanya orang yang punya perusahaan berusaha sedemikian rupa biar usaha yang mereka lakukan laku keras. Contoh pakaian, belakangan ramai negara kita dengan pakaian muslim, dulu tahun 90-an walaupun beragama Islam itu belum ada baju muslim kaya sekarang, paling baju kurung, kudungan disengklekin dengan perkembangan zaman teknologi yang maju makin canggih berpikiran ada baju-baju muslim yang atas bawah seragam senada dan seterusnya, modelnya macam-macam bahkan belakangan orang yang punya pabrik pakaian muslim itu kata mereka laku keras luar biasa. Benarkah itu? Bener. Karena sekarang mereka mengatakan pakaian muslimah itu pakaian yang trendi, gaya modelnya bagus-bagus dipikirkan oleh desainer bagaimana pakaian muslimah yang cantik, tapi kita sebagai seorang muslim

https://www.viva.co.id/siapa/read/120-Dedehrosidah. 
jangan asal makai baju doang ketutup aurat, mereketengteng, pating pecotot, orang jawa bilang itu salah, kenapa, itu mah sama dengan dengan leupet, sama dengan lontong, tahu leupet? Diikat luarnya direbus begitu bungkusnya dibuka persis kayak begitu. Artinya perempuan-perempuan yang mengenakan pakaian muslimah mereketengteng, pating pecotot itu temennya leupet, salah dalam Islam. Karena apa ini perhiasan Iho, pakaian ini perhiasan kita. Wahai anak keturunan Adam Kita semua laki-laki perempuan, telah aku turunkan buat kalian pakaian sebagai penutup buat aurat buat kalian.

Pakaian indah perhiasan buat kalian, pakaian taqwa yang terbaik buat kalian. Jadi fungsi pakaian nutup aurat artinya anda kalau pakai legging di luar itu salah atasnya segini, semuanya ngepres kelihatan. Bapakbapak walaupun kakek-kakek demen melihatnya, normal. Tuh jangan mengenakan pakaian yang begitu karena gaya hidup kita sesuai aturan agama. Bagaimana berpakaian yang baik jangan berlebihan. Jangan berlebihan Allah tidak suka dengan orang berlebihan. Apa yang berlebihan? Mulai dari rias wajah kadangkadang orang dandan kulitnya gak kelihatan, warna-warni bedak doang yang keliatan. Dalam Islam diharamkan. Jangan berlebihan Allah benci dengan orang yang berlebihan. Gaya hidup sekarang mobil mewah rumah mewah boleh punya rumah boleh, boleh. Boleh punya mobil, boleh. Tapi jangan lupa cara meraihnya Allah Ridho nggak, masyallah ini dunia cuma permainan. Al-Hadid ayat 20, ketahui oleh kalian dunia ini hanya permainan yang melalaikan, yang bermegah-megahan diantara kalian, banyak-banyak harta kekayaan dan anak keturunan pamer sama orang, kalau itu yang dilakukan mereka kemasukan setan.

Pamer dengan kekayaan pamer dengan pangkat pamer dengan jabatan artinya kemasukan setan, hubbuddunya. Islam hidupnya seimbang, sadar dunia sementara kita bakal mati dan kita mempertanggungjawabkan apa yang kita kerjakan di alam dunia. Tuntutlah oleh kalian apa yang Allah ajarkan tentang akhirat tapi jangan melupakan urusan dunia. Seimbang gak? Kerjakan apa yang Allah ajarkan tentang Akhirat, tapi jangan melupakan urusan dunia, seimbang gak? Akhirat kerjain, dunia kerjain, tapi akhirat lebih dominan. Kenapa? Karena itu nanti kita ke akhirat pekerjaan di dunia niatnya buat kebahagiaan di akhirat maka setiap Ibu mau ngapain mau ngapain mau ngapain mulai dengan basmalah dan akhiri dengan hamdalah.

Secara penutup Mamah Dedeh menyampaikan: Ini gaya hidup umat Islam, kenakan pakaian yang baik, bicara yang baik baik, bergaul dengan orang-orang baik, datang di pengajian dengan baik, masyallah pakaian takwa yang terbaik kepada kalian makanya jadilah kita orang-orang yang benar bertakwa kepada Allah yang bisa menyelamatkan kita sebagai seorang muslim selamat dunia sampai akhirat kita. Amin. $^{77}$

\section{Gaya Bahasa Mamah Dedeh dalam Ceramah Berjudul "Islam \& Gaya Hidup"}

77 Indosiar, "Islam Dan Gaya Hidup." 
Bagian analisis ini akan menjelaskan gaya bahasa yang digunakan oleh Mamah Dedeh dalam Ceramah yang berjudul "Islam \& Gaya Hidup". Dalam proses analisis akan disampaikan sesuai dengan tahapan dari struktur ceramah yang terdiri dari pengantar, kemudian isi dan terakhir penutup. Dari penjelasan tersebut, akan diketahui bagaimana penggunaan gaya bahasa Mamah Dedeh dalam setiap tahapan ceramah tersebut.

\section{Gaya Bahasa pada Pengantar Ceramah}

Dalam pengantar ceramah terdapat beberapa penyampaian yang dianggap sebagai gaya bahasa yakni: (a) penggunaan kata kaffah pada kalimat Makanya masuk Islam harus kaffah, masuklah Islam Kaffah serta artinya... Islamnya tidak kaffah; (b) penggunaan kalimat Jangan mengikuti langkah setan, setan musuh yang nyata.

Pengantar ceramah tersebut, Mamah Dedeh menggunakan beberapa gaya bahasa dalam penjelasannya. Pertama, penggunaan gaya bahasa repetisi saat menyampaikan kata kaffah dalam kalimat pengantar ceramahnya. Gaya bahasa repetisi sendiri termasuk dalam gaya bahasa berdasarkan struktur kalimat. Penggunaan kata kaffah yang berulang kali dan menjadi tekanan menunjukkan bahwa, hal itu ingin disampaikan dan bisa ditangkap oleh jemaah. Kata kaffah menurut Ibnu Katsir ${ }^{78}$ memiliki arti Allah memerintahkan kepada hamba-Nya agar berpegang kepada seluruh tali Islam dan syariatnya, mengerjakan perintah-Nya serta menjauhi semua larangan-Nya sekuat tenaga.

${ }^{78}$ Riana Ratna Sari, "Islam Kaffah Menurut Pandangan Ibnu Katsir," Ishlah: Jurnal Ilmu Ushuluddin, Adab Dan Dakwah 1, no. 2 (2019): 144-45, doi:10.32939/ishlah.v1i2.46.
Berdasarkan pengertian tersebut, kaffah berarti menunjukkan keseluruhan hidup didasarkan pada perintah dan larangan Allah. Maka, orang-orang yang tidak melakukan perintah dan melanggar perintah Allah dianggap sebagai seorang muslim yang tidak lengkap atau menyeluruh. Fungsi repetisi dari kata kaffah sendiri pada bagian pengantar ceramah bisa diartikan sebagai cara yang dilakukan oleh Mamah Dedeh untuk memfokuskan perhatian Jemaah karena, pembahasan ceramahnya berkaitan dengan gaya hidup yang tidak sedikit banyak berlawanan dengan perintah dan larangan Allah, dengan memberikan hal ini, maka jemaah akan menjadi memiliki pemahaman di awal bahwa seorang muslim harus menjalankan perintah dan larangan Allah tanpa terkecuali dan tidak mengikuti langkah setan yang bisa menjauhkan akan hal tersebut.

Kedua, penggunaan gaya bahasa personifikasi saat mengatakan jangan mengikuti langkah setan, setan musuh yang nyata. Gaya bahasa personifikasi sendiri termasuk dalam gaya bahasa kiasan. Penggunaan frasa ini, memberikan sifat kemanusian kepada benda-benda mati atau hal-hal yang tidak bernyawa, dari pernyataan tersebut menunjukkan bahwa, setan memiliki kaki sehingga dia bisa melangkah dan juga merupakan musuh yang nyata bagi manusia. Menurut M. Quraish Shihab, setan sendiri adalah sifat atau perilaku yang bersifat buruk, tidak menyenangkan, atau segala sesuatu yang buruk dan tercela. ${ }^{79}$ Jika mengacu pada pengertian tersebut, maka setan sendiri

79 M. Quraish Shihab, Setan Dalam Al-Quran Yang Halus Dan Tak Terlihat (Jakarta: Lentera Hati, 2010), 23. 
bukan atau berbeda dengan manusia dan tidak memiliki bentuk tubuh seperti manusia pada umumnya. Dalam bagian ini, terlihat bahwa ada gaya bahasa yang memberikan sifat kemanusiaan kepada sifat setan yang bermaksud untuk menunjukkan bahwa setan adalah musuh dari manusia yang nyata dan bisa dirasakan keberadaannya.

Penggunaan gaya bahasa ini, pada tahap pengantar bisa memberikan pemahaman dan asumsi yang sama sebelum masuk ke dalam isi ceramah. Dengan memberikan hal ini di awal, maka Mamah Dedeh memberikan semacam peringatan bahwa manusia seharusnya tidak melakukan perbuatan yang itu mencerminkan sifat setan, jika melihat dari penjelasan mengenai perilaku setan sendiri, perilaku yang dilakukan setan selalu merugikan, bertentangan dengan ajaran Islam. Penggunaan gaya bahasa ini menunjukkan bahwa, dalam pengantar Mamah Dedeh sudah memberikan sebuah pengingat bahwa setan adalah musuh. Layaknya musuh maka semua hal berkaitan dengan dirinya pasti akan dilawan atau ditentang. Hal ini, akan memberikan asumsi kepada para pendengar bahwa manusia memiliki musuh yakni setan. Jika dihubungkan dengan tujuan dalam pengantar, maka hal ini bisa sebagai pemberi perhatian kepada pokok pembahasan yang akan disampaikan oleh Mamah Dedeh. Hal ini, menunjukkan bahwa penggunaan gaya bahasa ini lebih mudah dipahami dan sesuai dengan fungsi pengantar.

Dari penjelasan tersebut, terlihat dalam tahap pengantar ceramah, Mamah Dedeh menggunakan beberapa gaya bahasa, yakni gaya bahasa repetisi dan personifikasi untuk memperjelas pengantar ceramah sebelum masuk kepada inti pesannya. Dalam pengantar ini, banyak menekankan untuk menjalankan Islam secara menyeluruh dan tidak pilih-pilih serta menjauhi dan memusuhi setan. Penggunaan kata kaffah dan setan sendiri tentu menjadi salah satu gaya bahasa yang khas dalam bagian pengantar ini.

\section{Gaya Bahasa pada Isi Ceramah}

Dalam isi ceramah terdapat beberapa penyampaian yang dianggap sebagai gaya bahasa yakni: (a) jangan asal makai baju...itu mah sama dengan leupet, sama dengan lontong; (b) penggunaan kalimat tahu leupet? Diikat luarnya direbus begitu bungkusnya dibuka persis kayak begitu; (c) penggunaan frasa pakaian ini perhiasan kita; (d) penggunaan frasa pakaian taqwa yang terbaik buat kalian; (e) penggunaan frasa masyallah ini dunia cuma permainan. AlHadid ayat 20, ketahui oleh kalian dunia ini hanya permainan yang melalaikan; (f) penggunaan frasa kalau itu yang dilakukan mereka kemasukan setan; (g) Tuntutlah oleh kalian apa yang Allah ajarkan tentang akhirat tapi jangan melupakan urusan dunia. Seimbang gak?; (h) Islam hidupnya seimbang,

Bagian isi ceramah yang disampaikan Mamah Dedeh, menggunakan beberapa gaya bahasa dalam penjelasannya. Pertama, penggunaan gaya bahasa persamaan atau simile dari penyataan (a) tahu leupet? Diikat luarnya direbus begitu bungkusnya dibuka persis kayak begitu; (b) itu mah sama dengan leupet, sama dengan lontong; (c) pakaian ini perhiasan kita. Gaya bahasa simile termasuk dalam gaya bahasa kiasan.

Pada pernyataan sama dengan leupet, sama dengan lontong itu memiliki makna bahwa apa yang dilakukan oleh wanita muslim jika memakai pakaian yang tidak sesuai syariat 
itu seperti leupet atau lontong. Leupet memiliki bentuk lonjong dengan dibungkus daun janur dan diikat melingkar dari atas sampai bagian bawah, secara bentuknya bagian yang sudah matang akan terlihat mengembang, bagian tersebut sangat menonjol melebihi ikatannya. Gambaran ini, digunakan untuk mencerminkan realitas wanita yang berpakaian tidak sesuai syariat, banyak bagian tubuhnya yang terlihat karena jenis pakaian yang dipakai sama seperti realitas leupet. Pernyataan ini merupakan gaya bahasa simile, karena memberikan persamaan dengan cara membandingkannya dengan hal lainnya. Hal ini, diperkuat dengan adanya kata "sama" yang juga merupakan salah satu kata yang menunjukkan penggunaan gaya bahasa simile. Persamaan yang dipilih Mamah Dedeh dipandang juga cukup unik, yakni Mamah Dedeh memilih persamaan realitas yang hendak dijelaskan dengan realitas makanan.

Pada pernyataan tahu leupet? Diikat luarnya direbus begitu bungkusnya dibuka persis kayak begitu itu memiliki makna bahwa, apa wanita muslim yang menggunakan pakaian serba ketat memiliki kesamaan dengan realitas leupet. Dalam pernyataan tersebut, Mamah Dedeh menjelaskan bagaimana realitas leupet itu mulai dari diikat, kemudian direbus, selesai direbus bungkusnya dibuka dan ketika dibuka bentuk leupet itu sama dengan pakaian wanita yang serba ketat. Ini menunjukkan bahwa, Mamah Dedeh memberikan semacam persamaan mengenai realitas berpakaian wanita yang serba ketat dengan realitas leupet ketika sudah direbus dan dibuka bungkusnya. Pemberian persamaan ini menunjukkan bahwa, Mamah Dedeh memberikan gambaran secara kongkrit dan realitas itu bisa dipahami oleh para pendengarnya. Persamaan yang diberikan berkaitan dengan penampilan berpakaian wanita yang serba ketat dengan realitas makanan leupet. Pemberian persamaan ini, dipandang sebagai cara untuk melekatkan pesan yang hendak disampaikan yakni, mengenai pakaian wanita yang ketat, untuk menunjukkan realitas bagaimana jika wanita menggunakan pakaian yang ketat disandingkan dengan realitas leupet yang itu memang mewakili dari gambaran wanita yang memakai pakaian tidak memperhatikan aurat dan serba ketat. Penggunaan ini bisa menjadi semacam pesan yang bisa mudah diingat oleh para jemaah.

Pada pernyataan pakaian ini perhiasan kita juga termasuk sebagai gaya bahasa simile karena, dalam pernyataan tersebut hendak menjelaskan pakaian itu sama dengan perhiasan. Walaupun dalam pernyataan tersebut, tidak ada kata yang eksplisit untuk menguatkan penggunaan gaya bahasa simile, namun secara penyataan bisa diidentifikasi bahwa ada dua realitas yang disampaikan yakni pakaian dan perhiasan.

Kedua, penggunaan gaya bahasa paradoks dari pernyataan mereka kemasukan setan. Gaya bahasa paradoks termasuk jenis gaya bahasa kiasan. Pada penyataan mereka kemasukan setan ini termasuk ke dalam gaya bahasa paradoks, gaya bahasa paradoks adalah gaya bahasa yang mengandung pertentangan dengan fakta yang ada. Pada konteks ini, menjelaskan tentang realitas mengenai perilaku manusia yang suka pamer kehidupan dunia. Mamah Dedeh menjelaskan hal tersebut, dengan ungkapan mereka kemasukan setan. Dalam realitasnya sendiri mereka ini merujuk kepada manusia, sedangkan manusia tidak mungkin kemasukan setan secara harfiah. Karena 
setan adalah sifat. Manusia sendiri kenyataannya tidak bisa kemasukan setan sebagai sebuah makhluk. Sehingga, penggunaan gaya bahasa ini merupakan paradoks karena bertentangan dengan fakta yang ada. Dari sisi penggunaan gaya bahasa ini sendiri, gaya bahasa ini bersifat untuk mempertegas maksud dari realitas orang yang pamer kehidupan dunia, hal itu dipandang oleh Mamah Dedeh bahwa, perilaku mereka sudah kemasukan setan. Sehingga, dari sini cukup memberikan gambaran kepada penonton bahwa realitas yang seperti itu secara status sama dengan mereka kemasukan setan.

Ketiga, penggunaan gaya bahasa erotesis pada pernyataan tuntutlah...seimbang gak? Gaya bahasa erotesis termasuk gaya bahasa retoris. Pada pernyataan tersebut, Mamah Dedeh seolah memberikan sebuah pertanyaan tentang bagaimana kehidupan dunia dan akhirat menurut jemaah berdasarkan yang sudah dijelaskan sebelumnya melalui ungkapan Tuntutlah oleh kalian apa yang Allah ajarkan tentang akhirat tapi jangan melupakan urusan dunia. Di akhir penyampaian ditambahkan pertanyaaan, dan pertanyaan itu sendiri tidak dijawab langsung oleh Mamah Dedeh. Gaya bahasa ini, biasanya digunakan jika memang pertanyaan itu memiliki satu kemungkinan jawaban guna mencapai efek yang mendalam. Hal ini menunjukkan bahwa, penggunaan gaya bahasa tersebut sebenarnya sudah cukup mampu membuat jemaah bisa menjawab sendiri pertanyaan tersebut. Sehingga, dari situ akan muncul keyakinan akan konsep kehidupan dunia dan akhirat. Jika dihubungkan dengan pembahasan mengenai gaya hidup sendiri sesuai dengan judul ceramah, maka hal itu memberikan penegasan bahwa dalam memilih gaya hidup harusnya tidak melupakan kehidupan akhirat, karena keduanya dalam kehidupan umat Islam memiliki porsi yang seimbang. Dengan begitu, pemberian gaya bahasa ini, mampu memberikan penekanan maksud yang disampaikan oleh Mamah Dedeh.

Keempat, penggunaan gaya bahasa elipsis pada pernyataan Islam hidupnya seimbang. Gaya bahasa elipsis termasuk gaya bahasa retoris. Gaya bahasa elipsis adalah gaya bahasa yang menghilangkan suatu unsur kalimat, namun bisa dengan mudah ditafsirkan sendiri oleh pembaca atau pendengar. Dalam konteks ini, merujuk kepada realitas yang menunjukkan bahwa orang Islam itu hidupnya seimbang. Seimbang di sini antara kehidupan duniawi dan akhirat. Penggunaan kata ini harusnya merujuk kepada kehidupan umat Islam mengenai akhirat dan urusan dunia. Sehingga, penggunaan pernyataan tersebut adalah gaya bahasa elipsis. Namun dalam penggunaannya, Mamah Dedeh hanya menyebutkan Islam saja sebagai hal yang mewakili umat Islam. Hal ini, menunjukkan bahwa Mamah Dedeh sudah bisa memastikan bahwa, dengan hanya dengan menyebutkan kata tersebut, maka para jemaah akan bisa langsung menghubungkan sendiri, bahwa yang dimaksud itu adalah umat Islam. Dari penjelasan ini, jika dihubungkan dengan gaya hidup umat Islam sendiri memiliki makna bahwa, dalam ajaran Islam itu menekankan adanya keseimbangan dalam dunia dan akhirat. Hal itu, membuat gaya hidup yang dipilih harusnya juga tidak hanya aspek dunia saja, namun aspek akhirat juga harus diperhitungkan yakni dengan memperhatikan tata cara berpakaian yang diajarkan dalam agama Islam. Dengan 
begini, maka pesan yang hendak disampaikan akan lebih mudah dipahami.

Kelima, penggunaan gaya bahasa inuendo pada pernyataan dunia cuma permainan. Gaya bahasa inuendo termasuk gaya bahasa kiasan. Gaya bahasa inuendo adalah gaya bahasa sindiran dengan mengecilkan kenyataan yang sebenarnya. Dalam konteks ini, dunia yang memiliki banyak sekali makhluk dan kondisi alam, seperti manusia, hewan, pegunungan, dan lain sebagainya dianggap sebagai sebuah permainan yang bersifat sementara dan tidak serius. Hal ini menunjukkan bahwa dalam penyataan ini, Mamah Dedeh hendak melakukan sebuah sindiran kepada orang-orang yang gaya hidupnya terlalu bermegah-megahan dan tidak menggunakan perintah Allah sebagai dasar gaya hidup. Dunia yang begitu mereka kejar dan lomba-lomba untuk menjadi yang paling banyak memiliki harta dipandang keliru karena sebenarnya kehidupan di dunia ini hanya sementara dan sebentar, sedangkan kehidupan akhirat adalah kehidupan yang abadi. Gaya bahasa ini, memberikan kesan bahwa orang-orang yang mengejar kehidupan dunia tanpa memperhatikan ajaran Islam akan menyesal, karena dunia sangat bersifat sementara dan tidak kekal. Jika dihubungkan dengan isi ceramah, maka penggunaan gaya bahasa ini bisa mendukung penyampaian pesan tersebut, karena dengan menyindir orang yang terlalu mengejar dunia tanpa menghiraukan ajaran Islam akan sangat merugi, oleh karena itu disebutkan bahwa dunia itu cuma permainan.

Jika melihat isi pesan yang disampaikan oleh Mamah Dedeh, dalam menyampaikan isi pesannya, berdasarkan teori ceramah maka hal ini termasuk dalam kategori deduktif. Isi pesan ceramah Mamah Dedeh, diawali dengan menjelaskan mengenai konsep gaya hidup secara umum, lalu kemudian menjelaskan lebih terperinci mengenai gaya hidup dalam Islam seperti pakaian, rias wajah, kepemilikan kendaraan sampai dengan rumah yang semuanya harus dicapai dengan cara-cara yang baik menurut Islam.

Dari penjelasan tersebut, terlihat dalam tahap isi ceramah, Mamah Dedeh menggunakan beberapa gaya bahasa, yakni gaya bahasa simile, paradoks, erotesis, elipsis, dan inuendo untuk menjelaskan inti pesan yang disampaikan yakni mengenai gaya hidup dalam Islam. Dalam isi ceramah ini, ada beberapa hal yang disampaikan yakni, menyamakan perilaku berpakaian yang tidak sesuai syariat dengan realitas makanan leupet, selain itu juga menyamakan pakaian seperti perhiasan yang perlu dijaga. Fungsi gaya bahasa simile ini untuk memberikan gambaran yang jelas mengenai perilaku yang menyimpang, dengan harapan realitas itu akan lebih mudah diterima dan diinternalisasi oleh jemaah. Gaya bahasa paradoks memiliki fungsi untuk memberikan ketegasan bahwa perilaku bermewahan dan pamer kehidupan dunia merupakan perilaku setan. Gaya bahasa erotesis dan elipsis memiliki fungsi untuk memberikan penekanan akan kehidupan umat Islam yang memegang prinsip keseimbangan dalam hal dunia dan akherat. Gaya bahasa inuendo memiliki fungsi memberikan sindiran dan menunjukkan kerugian orang yang terlalu mengejar kehidupan dunia dan mengabaikan ajaran Islam.

\section{Gaya Bahasa pada Penutup Ceramah} Penutup ceramah yang disampaikan Mamah Dedeh, terdapat penggunaan gaya bahasa personifikasi dalam penjelasannya. Pertama, 
penggunaan gaya bahasa personifikasi dari pernyataan pakaian yang baik. Gaya bahasa personifikasi termasuk gaya bahasa kiasan. Pernyataan ini, memberikan sifat kemanusiaan kepada benda mati. Dalam penyataan ini, yang diberikan sifat adalah pakaian dengan sifat baik. Dalam konteks ini, Mamah Dedeh menggunakan hal tersebut untuk menjelaskan dan memberikan penekanan hal-hal yang harus diperhatikan oleh kaum muslim untuk bisa mendapatkan akhirat dalam aspek gaya hidup. Maksud dari pakaian yang baik merujuk pada uraian pakaian yang dijelaskan pada tahap isi ceramah, pakaian yang baik tidak hanya menutup aurat, namun juga harus tidak memperlihatkan lekuk tubuh. Penggunaan gaya bahasa ini memberikan pengingat pada jemaah agar mengingat tentang norma berpakaian dalam Islam. Hal ini, selaras dengan maksud dan tujuan dari penutup yakni, memfokuskan pikiran dan gagasan pendengar kepada gagasan utama yang disampaikan. Konteks ini Mamah Dedeh menjelaskan, dengan kalimat yang singkat untuk memfokuskan gagasan utamanya tersebut. Penggunaan gaya bahasa Mamah Dedeh, dalam personifikasi ini mencoba untuk menghubungkan antara pakaian yang menjadi pesan dalam dakwahnya, dengan sifat baik, yang juga menjadi topik pembahasan dakwahnya. Kedua kata ini baik kata pakaian dan baik memiliki hubungan dengan pesan yang digunakan oleh Mamah Dedeh dalam ceramahnya. Sehingga, pesan yang diterima bisa lebih kuat dalam benak jemaah.

Kedua, penggunaan gaya bahasa personifikasi dari penyataan pakaian takwa yang terbaik. Personifikasi dalam pernyataan ini adalah pemberian status takwa terhadap realitas pakaian, status takwa umumnya dilekatkan kepada manusia bukan pakaian. Penggunaan gaya bahasa ini, menunjukkan Mamah Dedeh hendak menjelaskan pakaian yang baik merupakan salah satu hal yang harus dilakukan oleh umat Islam. Penggunaan kata pakaian dengan takwa ini, sama dengan isi pesan yang disampaikan yakni berpakaian sesuai dengan syariat. Kata takwa yang digunakan dipandang memiliki kekhasan jika disandingkan dengan pakaian karena hendak menunjukkan sebuah status pakaian yang mencerminkan sebuah ketakwaan. Hal ini juga tidak lepas dari tema besar yang dibahas dalam ceramah yakni, mengenai gaya hidup Islam yang salah satunya membahas mengenai gaya berpakaian. Penggunaan ini bersifat penutup, maka Mamah Dedeh tidak perlu mengulang kembali maksudnya, sehingga hanya dengan menjelaskan dengan kalimat yang lebih singkat hal tersebut bisa dipahami maksudnya. Jika dihubungkan dengan penutup sebagai pemfokusan pikiran, maka hal ini bisa termasuk dalam kategori itu. Karena dengan memberikan penyataan yang lebih singkat dan ringkas orang bisa dengan mudah mengingat dan mengerti apa kesimpulan yang harus dipahami dari ceramah yang dilakukan oleh Mamah Dedeh sendiri.

Dari penjelasan tersebut, terlihat dalam tahap penutup ceramah, Mamah Dedeh hanya menggunakan satu gaya bahasa yakni personifikasi untuk memberikan penegasan mengenai isi pesan yang sudah disampaikan. Dalam penutup ini, gaya bahasa personifikasi membantu memberi tekanan mengenai cara berpakaian yang merupakan pesan utama yang hendak disampaikan dalam ceramah ini. 
Dalam memberikan penutup ceramah, Mamah Dedeh menggunakan beberapa cara dalam menutup ceramahnya mengenai Islam dan Gaya Hidup yakni, memberikan gagasan dengan kalimat yang singkat, selain itu juga disertai dengan memberikan dorongan untuk bertindak yang itu tercermin dalam pernyataan "Kenakan pakaian yang baik, bergaul dengan orangorang baik, datang di pengajian dengan baik."

Dari keseluruhan gaya bahasa yang digunakan, terdapat kekhasan yang digunakan oleh Mamah Dedeh yakni, setiap gaya bahasa yang digunakan disesuaikan dengan pembahasan materi yang sedang disampaikan. Dalam ceramah tersebut, gaya bahasa yang digunakan selalu terkait dengan gaya hidup dalam Islam seperti, mengenai bagaimana aturan dalam berpakaian khususnya para wanita muslim, termasuk juga menjelaskan perilaku setan yang berlawanan dengan hukum Islam, sampai pada fenomena bermewahan yang ada di masyarakat. Penggunaan gaya bahasa, juga dilekatkan dengan pemberian status seperti baik dan takwa untuk mencerminkan pakaian yang sesuai dengan syariat Islam.

\section{Kesimpulan}

Dari penjelasan analisis di atas, maka dapat disimpulkan bahwa, Mamah Dedeh pada bagian pembuka menggunakan gaya bahasa repetisi dan personifikasi. Personifikasi digunakan untuk membangun asumsi dan pemahaman yang sama dengan para jemaah atau penonton. Untuk repetisi digunakan untuk memberikan kesamaan agar menjalankan Islam secara keseluruhan dan menjauhi dan memusuhi setan yang bisa menjauhkan dari ajaran Islam kepada penonton atau jemaah. Hal ini, sejalan dengan fungsi pada pembukaan yakni sebagai pengantar sebelum ke isi pesannya. Penggunaan kata kaffah dan setan menjadi salah satu gaya bahasa yang khas pada bagian pengantar.

Pada bagian isi menggunakan gaya bahasa simile, paradoks, erotesis, elipsis dan inuendo. Simile digunakan untuk mempermudah pemahaman akan realitas yang disampaikan kepada para jemaah dengan persamaan yang analog dan tidak harus dalam realitas yang sama, melainkan juga dengan realitas yang tidak serupa/sejenis. Mamah Dedeh dalam pemilihan realitas, untuk menunjukkan persamaan menghubungkan dengan realitas makanan untuk mempermudah pemahaman. Untuk paradoks digunakan untuk mempertegas maksud dari orang yang mengejar kehidupan dunia. Gaya bahasa paradoks yang digunakan berkaitan dengan kemasukan setan. Untuk gaya bahasa erotesis dan elipsis menekankan akan kehidupan yang seimbang antara dunia dan akhirat bagi umat Islam. Untuk gaya bahasa inuendo menekankan bahwa, mengejar kehidupan dunia tidak memperhatikan ajaran Islam maka akan sia-sia karena dunia hanya bersifat sementara.

Pada bagian penutup menggunakan gaya bahasa personifikasi. Personifikasi digunakan untuk pengingat kepada jemaah atas apa yag disampaikan sebelumnya dengan penyataan yang lebih singkat dan ringkas.

Untuk studi selanjutnya, berkaitan dengan gaya bahasa ini bisa melakukan kajian lanjutan terhadap media dakwah yang selainnya, seperti novel, cerpen, ataupun 
puisi yang juga cukup banyak dijadikan sebagai media dakwah saat ini. Diharapkan dengan adanya hasil ini, memberikan inspirasi penggunaan gaya bahasa bagi para pendakwah dalam ceramah ataupun teknik selainnya yang menekankan penggunaan kata/kalimat dalam berdakwah, untuk kepentingan menyampaikan ajaran agama Islam kepada umat Islam agar pesan yang diterima bisa lebih membekas dan tertanam dalam benak jemaah.

\section{Bibliografi}

A.R, Nurmy. "Gaya Bahasa Dakwah Di Daerah Pesisir." Al-Hikmah 10, no. 1 (2016). doi:10.24260/al-hikmah.v10i1.545.

Anjani, Eka. “Gaya Bahasa K.H. Zainuddin M.Z. Dalam Ceramah Isra Mikraj Di Tanggerang Selatan." Inteleksia-Jurnal Pengembangan IImu Dakwah Volume 1, no. 01 (2019): 161-85. http://inteleksia.stidalhadid.ac.id/index.php/inteleksia/article/view/17.

Aulia, Burhanuddin. "Hedonisme Dalam Novel Antologi Rasa Karya Ika Natassa." Jurnal Bahasa Dan Sastra 6, no. 3 (2019): 458. doi:10.24036/81037410.

Aziz, Ali. Ilmu Dakwah Edisi Revisi. Surabaya: Prenada Media Group, 2016.

Harlie, Stefanny, and Widayatmoko Widayatmoko. "Analisis Wacana Perilaku Konsumtif Dalam Film Crazy Rich Asian." Koneksi 2, no. 2 (2019): 584. doi:10.24912/kn.v2i2.3940.

Husen, Deary Pratama, and Agus Wartiningsih. "Analisis Gaya Bahasa Dalam Slogan Makanan Ringan." Jurnal Penddikan Dan Pembelajaran Khatulistiwa 7(9) (2018): 1-8. https://jurnal.untan.ac.id/index.php/jpdpb/article/view/28868.

Indonesia, Komisi Penyiaran. Survei Indeks Kualitas Program TV Periode II (April-Juni) 2018, 2018. http://www.kpi.go.id/index.php/id/umum/38-dalam-negeri/34754-hasil-surveyindeks-kualitas-program-tv-periode-ii-april-juni-2018.

Indosiar. "Islam Dan Gaya Hidup." Indonesia, 2016. http://youtu.be/98x04eljKd0.

Keraf, Gorys. Diksi Dan Gaya Bahasa. Jakarta: Gramedia Pustaka Utama, 2010.

Mubasyaroh. "Dakwah Dan Komunikasi (Studi Penggunaan Media Massa Dalam Dakwah)." Jurnal Komunikasi Penyiaran Islam 4, no. 1 (2016): 95-114. doi:10.21043/attabsyir.v4i1.2908.

Nata, Abuddin. Perspektif Islam Tentang Strategi Pembelajaran. Jakarta: Kencana Prenada Media Grup, 2011.

Ninit Alfianika. "BAHASA BETAWI DAN GAYA BAHASA REPETISI DALAM CERAMAH USTAD YUSUF MANSUR PROGRAM WISATA HATI DI ANTV." JURNAL GRAMATIKA 1, no. 1 (2016): 110-22. doi:10.22202/jg.2015.v1i1.1161.

Nizar, Samsul dan Zainal Efendi Hasibuan. Hadis Tarbawi, Membangun Kerangka Pendidikan Ideal Perspektif Rasulullah. Jakarta: Kalam Mulia, 2011.

Noor, Shafira Rianiesti. "Gaya Dakwahnya Sering Dijadikan Parodi, Mamah Dedeh Justru Bangga Dan Bersyukur." Accessed April 27, 2020. https://palembang.tribunnews.com/2018/06/11/gaya-dakwahnya-sering-dijadikanparodi-Mamah-Dedeh-justru-bangga-dan-bersyukur.

Nurin, Fajarina. "Terkenal Ceplas-Ceplos Mamah Dedeh Terpilih Jadi Ulama Penutan." 
Accessed November 15, 2019.

https://www.liputan6.com/showbiz/read/3138905/terkenal-ceplas-ceplos-MamahDedeh-terpilih-jadi-ulama-panutan.

Ratna Sari, Riana. "Islam Kaffah Menurut Pandangan Ibnu Katsir." Ishlah: Jurnal Ilmu

Ushuluddin, Adab Dan Dakwah 1, no. 2 (2019): 132-51. doi:10.32939/ishlah.v1i2.46.

Sabarisman, Muslim. "Gaya Hidup Hedonisme Dan Fenomena Trafficking Anak : Studi Kasus Di Kota Surabaya." Sosiokonsepsia 16, no. 2 (2011): 187-96. doi:10.33007/ska.v16i2.802.

Samhudi, Obi, Chairil Effendy, and Christanto Syam. "Jenis Dan Fungsi Gaya Bahasa Dalam Pemaknaan Kumpulan Cerpen Kembalinya Tarian Sang Waktu: Stilistika." Jurnal Pendidikan Dan Pembelajaran Khatulistiwa 6, no. 12 (2017): 6. https://jurnal.untan.ac.id/index.php/jpdpb/article/view/23107.

Saputri, Ardilla, and Risana Rachmatan. "Religiusitas Dengan Gaya Hidup Hedonisme: Sebuah Gambaran Pada Mahasiswa Universitas Syiah Kuala." Jurnal Psikologi 12, no. 2 (2017): 59. doi:10.24014/jp.v12i2.3230.

Shihab, M. Quraish. Setan Dalam Al-Quran Yang Halus Dan Tak Terlihat. Jakarta: Lentera Hati, 2010.

Sugiyono. Metode Penelitian Kuantitatif Kualitatif Dan R\&D. Bandung: Alfabeta, 2012.

-- - Metode Penelitian Pendidikan Pendekatan Kuantitatif, Kualitatif, Dan R\&D. Bandung: Alfabeta, 2015.

Syahrin, Alfi. "Kajian Retorika Dakwah Mamah Dedeh Akselerasi Pemahaman Dalam Seni Berbicara." Pendidikan Almuslimin Volume 3, no. 2 (2015): 1. http://jfkip.umuslim.ac.id/index.php/jupa/article/view/413.

Tempo. "Mamah Dedeh: Program Religi Televisi Terpopuler." Tempo. Accessed November 15, 2019. https://seleb.tempo.co/read/728412/Mamah-Dedeh-program-religi-televisiterpopuler-2015.

Utami, Adrina Inayati, Reni Nuraeni, and Syarif Maulana. "Representasi Wanita Sosialita Dalam Iklan ( Analisis Semiotika Roland Barthes Pada Iklan Televisi Magnum Versi Pink and Black ) Representation of Socialite Woman in Advertising ( Semiotic Analysis of Roland Barthes in Television Advertising of Magnum Pink." E-Proceeding of Management 2, no. 3 (2015): 4279-86.

https://openlibrarypublications.telkomuniversity.ac.id/index.php/management/article/vi ew/2442.

Viva.co.id. "Profil Mamah Dedeh." Viva. Accessed April 27, 2020. https://www.viva.co.id/siapa/read/120-Dedeh-rosidah.

Zaini, Ahmad. "Retorika Dakwah Mamah Dedeh Dalam Acara 'Mamah \& Aa Beraksi' Di Indosiar." Ilmu Dakwah: Academic Journal for Homiletic Studies 11, no. 2 (2018): 219-34. doi:10.15575/idajhs.v11i2.1900.

Zhafira, Atha. "Pengaruh Program Mamah Dan Aa Beraksi Episode 'Nistanya Zina Dan Penyimpangan Seksual' Terhadap Tingkat Kesadaran Remaja Akan Bahaya Zina (Survey Pada Siswa/Siswi Sman 87 Dki Jakarta." Skripsi UIN Syarif Hidayatullah, 2017. https://repository.uinjkt.ac.id/dspace/handle/123456789/35337. 
Eko Agoes Setiawan

168 | INTELEKSIA - Jurnal Pengembangan IImu Dakwah 